\title{
Overcoming Compaction Limitations on Cabbage Growth and Yield in the Transition to Reduced Tillage
}

\author{
Maren J. Mochizuki, Anusuya Rangarajan', and Robin R. Bellinder
} Department of Horticulture, Cornell University, 22 Plant Sciences Building, Ithaca, NY 14853

Thomas Björkman

Department of Horticultural Sciences, New York State Agricultural Experiment Station, Cornell University, Geneva, NY 14456

Harold M. van Es

Department of Crop and Soil Sciences, Cornell University, 235 Emerson Hall, Ithaca, NY 14853

Additional index words. Brassica oleracea var. capitata, conservation tillage, minimum tillage, zone tillage, strip tillage, vegetable production, soil temperature, soil quality

\begin{abstract}
Vegetable producers are increasingly interested in adopting conservation tillage practices to maintain or enhance productivity and soil health, but reducing tillage may reduce yields in cool climates. Strategies to transition from full-width tillage to zone tillage systems for cabbage (Brassica oleracea $L$. Group capitata) were tested with the goals of overcoming soil temperature and compaction limitations and producing crop yield and quality equivalent to conventionally tilled. Designed to achieve differential soil temperature and compaction levels, the treatments were factorial combinations of two widths of zone tillage $(15$ and $30 \mathrm{~cm})$ and two depths of zone tillage $(10$ and $30 \mathrm{~cm})$ plus a conventional rototilled treatment (full width and $20-\mathrm{cm}$ depth) as a control. To assess the effect of treatments in the transitional year to reduced tillage, the experiment was conducted in 2003 and 2004 at different fields that were previously conventionally tilled. Increasing tillage width from $15 \mathrm{~cm}$ to $30 \mathrm{~cm}$ increased soil temperature by $1^{\circ} \mathrm{C}$ in both years but had a limited effect on cabbage growth and no effect on yield. Tillage width and soil temperature may have greater impact on an earlier planting. By contrast, increasing tillage depth from $10 \mathrm{~cm}$ to $30 \mathrm{~cm}$ reduced soil penetrometer resistance by up to $1 \mathrm{MPa}$, increased plant growth by $28 \%$, and increased yield by $22 \%$. Growth and yield in $30-\mathrm{cm}$ depth treatments were similar to conventional tillage, indicating the undisturbed, between-row areas in zone tillage treatments did not restrict growth. Zone tillage did not affect cabbage maturity or quality. Tillage depth was more important to the success of this system than tillage width; vertical tillage to $30-\mathrm{cm}$ depth left between $60 \%$ and $80 \%$ of the soil surface area undisturbed and can be an effective transition to conservation tillage for transplanted cabbage.
\end{abstract}

In a cool, rainy climate such as the northeastern United States, field operations in vegetable systems are often based on stringent production schedules rather than ideal soil moisture conditions (Wolfe et al., 1995). Cabbage production is particularly susceptible to a decline in soil quality because field operations are often required when the soil is wet, both early in the spring and the late fall (Reiners, 2004).

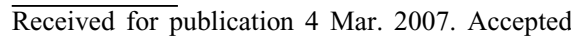
for publication 8 July 2007.

Funding for this research was received from the Northeast Sustainable Agriculture Research and Education Program.

We thank Betsy Ingall, Steve McKay, William Ketchum, and Dave Becker for on-farm technical support and Karen Grace-Martin and Francoise Vermeylen for statistical consultation.

${ }^{1}$ To whom reprint requests should be addressed; e-mailar47@cornell.edu
}

Conservation tillage, any practice that minimizes soil and water loss and maintains $30 \%$ surface cover with cash or cover crop residue (Soil Science Society of America, 2005), could potentially balance some of the negative production-based impacts on soils. In practice, conservation tillage can be achieved by minimizing tillage operations temporally and spatially (e.g., reducing the number of times over a field or in the width or depth tilled) and managing surface residues (Magdoff and van Es, 2000). Research in conservation tillage has been ongoing since the 1960s and its success and adoption in agronomic crops such as field corn is well documented (Bentley, 1977; Cox et al., 1992; Young and Phillips, 1973).

Adoption of conservation tillage for vegetable crops grown in the Northeast, however, has been slow despite years of study with no tillage (directly seeding or transplanting into residue) or zone tillage (tillage within the planting zone of $\approx 10$ to $15 \mathrm{~cm}$ width and depth). The primary reasons for limited adoption are reduced yields and delayed harvest for crops such as winter squash, tomatoes, and peppers (Loy et al., 1987; McKeown et al., 1988; Teasdale and Mohler, 1993; Johnson and Hoyt, 1999). The lack of tillage coupled with residue on the soil surface maintains cooler soil temperatures for longer periods in the spring (Teasdale and Mohler, 1993) and may explain much of the discrepancy of success for conservation tillage production between northern and southern climates.

Compaction is another yield-limiting factor in the transitional years to conservation tillage (Magdoff and van Es, 2000). For example, no-till soil is often more resistant to penetration than soil prepared by moldboard or a chisel plow in the first 2 years, particularly in the surface 7 to $8 \mathrm{~cm}$ (Kline, 1984). Moreover, cabbage plants are particularly sensitive to compaction with biomass and yield reduction as high as $60 \%$ and $70 \%$, respectively (Wolfe et al., 1995).

The goal of this study was to overcome initial vegetable yield reductions associated with the transition to conservation tillage in cool climates by establishing reduced tillage treatments in a different field each year that had been previously conventionally tilled. Because tillage affects soil surface roughness and therefore reflection and retention of heat (Cruse et al., 1982) and can break previously compacted soil layers, zone tillage treatments were modified by width and depth of tillage to examine the relative importance of these two potential yield-reducing factors associated with transitioning to reduced tillagecool soil temperature and high soil penetration resistance - and to identify the amount of tillage that maximized conservation values without reducing cabbage yield.

\section{Materials and Methods}

Cultural practices and experimental design

Plots were established in 2003 and 2004 at the Homer C. Thompson Vegetable Research Farm at Freeville, NY. Different fields were used each year to study the transition to conservation tillage. Each field had the same soil type, Howard gravelly loam (Glossoboric Hapludalf, loamy skeletal mixed mesic). Previous crops were dry beans (Phaseolus vulgaris L.) in 2002 and pumpkins (Cucurbita pepo) in 2003, each followed by cereal rye (Secale cereale L.) seeded at a rate of $190 \mathrm{~kg} \cdot \mathrm{ha}^{-1}$.

Fertilizer was broadcast at rates based on soil test results and recommendations for transplanted cabbage (Reiners, 2004): 68 $\mathrm{kg} \cdot \mathrm{ha}^{-1}$ of nitrogen $(\mathrm{N}), 34 \mathrm{~kg} \cdot \mathrm{ha}^{-1}$ of phosphorus $(\mathrm{P})$, and $34 \mathrm{~kg} \cdot \mathrm{ha}^{-1}$ of potassium $(\mathrm{K})$ in 2003 and $68 \mathrm{~kg} \cdot \mathrm{ha}^{-1}$ of $\mathrm{N}$ and $89 \mathrm{~kg} \cdot \mathrm{ha}^{-1}$ of $\mathrm{P}$ in 2004. An additional $68 \mathrm{~kg} \cdot \mathrm{ha}^{-1}$ of $\mathrm{N}$ as ammonium nitrate was sidedressed by hand at the cabbage cupping stage in both years. 
Tillage treatments were established 3 to 5 $\mathrm{d}$ before transplanting. First, a subsoiling implement (Tuf-line; Monroe, Columbus, MS) with gauge wheels tilled to $10-$ and $30-\mathrm{cm}$ depths (Table 1). This vertical tillage was followed by a single pass of three eight-wave coulters (Rawson; Farwell, MI) (each wave $17 \mathrm{~cm}$ in length) per row to establish 15 - and $30-\mathrm{cm}$ widths of disturbed soil (Table 1). Conventional tillage was approximated using a rototiller (model B180C; Maschio, Campondansego, Italy) to a depth of $20 \mathrm{~cm}$ in both bare and mulched plots.

The experimental design was a randomized complete block with four replications. Each subplot had four plant rows and measured $7.6 \times 9.1 \mathrm{~m}$.

Cabbage 'Fresco' seeds, treated with thiram, iprodione, and metalaxyl fungicides, were planted in trays with 162 cells $(50 \times$ $25 \times 3.8 \mathrm{~cm}$ ). Day and night temperatures in the greenhouse were $\approx 24$ and $10^{\circ} \mathrm{C}$, respectively. Transplants were moved outdoors to a coldframe 1 week before planting. A no-till transplanter (model RJV600; RJ Equipment, Blenheim, Ontario, Canada) was used to plant seedlings on 9 June 2003 and 7 June 2004. Between-row spacing was $76 \mathrm{~cm}$ and in-row spacing was $36 \mathrm{~cm}$ between plants. Skips or misplaced plants were transplanted by hand the next day.

Glyphosate was applied to kill the rye and may have provided some weed control. Further control was achieved with pretransplant oxyfluorfen $\left(2.4 \mathrm{~L} \cdot \mathrm{ha}^{-1}\right.$ product) and posttransplant s-metolachlor (1.2 $\mathrm{L} \cdot \mathrm{ha}^{-1}$ product).

Plants were scouted weekly for flea beetles (Phyllotreta cruciferae) using a damage threshold of eight beetles per plant in 2003. In 2003 , both permethrin $\left(0.44 \mathrm{~L} \cdot \mathrm{ha}^{-1}\right.$ product $)$ and lamda-cyhalothrin $\left(0.28 \mathrm{~L} \cdot \mathrm{ha}^{-1}\right.$ product $)$ were applied once each for control. The threshold was reduced to five flea beetles per plant in 2004, and plants were sprayed once each with carbaryl (1.1 $\mathrm{kg} \cdot \mathrm{ha}^{-1}$ product), endosulfan $\left(2.4 \mathrm{~L} \cdot \mathrm{ha}^{-1}\right.$ product $)$, permethrin (0.44 $\mathrm{L} \cdot \mathrm{ha}^{-1}$ product), and lamda-cyhalothrin (0.22 L $\cdot$ ha $^{-1}$ product).

Irrigation to supplement rainfall in 2003 was applied three times based on gypsum moisture block readings less than 50\% saturation (model 5910A; Soil Moisture Equipment Corp., Santa Barbara, CA). No supplemental irrigation was necessary in 2004. Both seasons had higher than average precipitation. With $160 \mathrm{~mm}$ in July 2003, rainfall exceeded the 30 -year average by $78 \%$; in 2004 , both July $(240 \mathrm{~mm})$ and August $(172 \mathrm{~mm})$ exceeded the 30-year average by $167 \%$ and $100 \%$, respectively (Northeast Regional Climate Center, 2004).

Table 1. Tillage treatments for conservation tillage cabbage trials in 2003 and 2004 at Freeville, NY.

\begin{tabular}{lcc}
\hline Width $(\mathrm{cm})$ & Depth $(\mathrm{cm})$ & Volume $\left(\mathrm{cm}^{3}\right)$ \\
\hline 15 & 10 & 150 \\
30 & 10 & 300 \\
15 & 30 & 450 \\
30 & 30 & 900 \\
70 (full width) & 20 & 1400 \\
\hline
\end{tabular}

\section{Plant measurements}

Aboveground biomass sampling. Three plants per plot were destructively sampled at $14,28,58$, and $71 \mathrm{~d}$ after planting (DAP) in 2003 and 14, 29, 44, 56, and 71 DAP in 2004. Plants were randomly chosen from the two center rows of each plot and cut at the soil line. Each sampled plant had all neighbors intact to avoid sampling bias. Plant fresh and dry weight (after oven-drying at $41^{\circ} \mathrm{C}$ ) were recorded.

Harvest yield and quality. Head yield and quality were sampled from a $2.7-\mathrm{m}^{2}$ area in the center of each plot. The areas were harvested twice, 77 and 91 DAP in 2003 and 80 and 93 DAP in 2004, in case maturity was delayed in some treatments. Because there were no treatment differences in maturity, yield data from both harvests were summed for analysis. Three representative heads from each plot were cut in half to assess internal characteristics and quality. Head length and width and core length and width were measured. Overall head appearance, including external color, blemishes, and density, was qualitatively assessed on a point scale ranging from poor (1) to excellent (5).

\section{Soil measurements}

Soil temperature. Thermocouples were installed $15 \mathrm{~cm}$ below the soil surface in the plant row $10 \mathrm{~d}$ after planting in 2003 and $1 \mathrm{~d}$ after planting in 2004. Soil temperatures were recorded every hour using an AM 416 Multiplexer with a CR10X datalogger (Campbell Scientific, Logan, UT); data were output as mean temperatures every $2 \mathrm{~h}$.

To analyze variation within a 48 -h period, we examined bihourly temperatures at the beginning and end of an 8-d period preceding an increased rate of plant growth: 22 to 23 and 27 to 28 DAP in 2003 and 19 to 20 and 24 to 25 DAP in 2004 . To analyze variation within the entire 8-d interval, the maximum and minimum temperatures were calculated for each day between 22 and 29 DAP in 2003 and between 19 and 26 DAP in 2004. Soil temperature was measured for the entire season, but analysis of data at the middle and end of the season indicated no differences (data not shown).

Penetrometer resistance. Soil resistance to penetration as a function of depth was assessed by averaging three in-row measures per plot. In 2003, a Bush recording cone-tip penetrometer (Findley, Midlothian, Scotland), registering every $3.5 \mathrm{~cm}$ to a depth of $31.5 \mathrm{~cm}$, was used 16 and 106 DAP. In 2004 , resistance was measured 17 and 104 DAP using a Rimik CP20 recording cone-tip penetrometer (Agridry, Toowomba, Australia) every $2.5 \mathrm{~cm}$ to a depth of $30 \mathrm{~cm}$. Soil water content consistently ranged from 0.11 to $0.13 \mathrm{~g} \cdot \mathrm{g}^{-1}$ at the time of sampling for both years (data not shown). This soil type was up to $50 \%$ stones by volume, which resulted in higher penetrometer resistance values than equivalent root penetration resistance in a nonstony soil; the penetrometer resistance values presented are comparable among these treatments only. Although the estab- lished threshold of 3.0 $\mathrm{MPa}$ to limit plant growth in coarse-textured soils (Laboski et al., 1998) may not be applicable to all the values presented, it is included in figures as a point of reference.

\section{Statistical analyses and data presentation}

Analysis of variance to determine tillage treatment effects and their interaction was performed using the SAS Mixed procedure (SAS systems, Cary, NC). Multiple comparisons were performed with the overall error rate controlled by Tukey-Kramer or Bonferroni adjustment. Contrasts were performed when appropriate, grouping tillage treatments by width and depth. Because of significant treatment-by-year interactions, data were analyzed and presented within each year. Tillage width was not found to be a significant factor affecting soil penetrometer resistance and tillage depth was not found to be a significant factor affecting soil temperature; data are therefore presented by factor.

\section{Results and Discussion}

Conservation tillage has the potential to inhibit growth by reducing soil temperature, but this trend was not observed in this study. Reduced tillage treatments (15- and $30-\mathrm{cm}$ width) had minimal effect on soil temperature on each day sampled in 2003; soils were cooler by $1{ }^{\circ} \mathrm{C}$ or less compared with fullwidth tillage $(70 \mathrm{~cm})$ only between 2200 and 2400 HR $(P<0.10$; Fig. 1A-B). In 2004, treatments tilled to $15-\mathrm{cm}$ width were cooler than both the $70-\mathrm{cm}$ and $30-\mathrm{cm}$ width treatments $(P<0.10)$ between 2000 and $2400 \mathrm{HR}$ 19, 20, and 24 DAP (Fig. 1D-E), but temperature differences were also less than $1^{\circ} \mathrm{C}$. Although narrow tillage did not affect daily maximum temperatures, daily minimum soil temperatures for treatments tilled to 30 - and $15-\mathrm{cm}$ width were cooler than those tilled to $70-\mathrm{cm}$ width between 22 and 29 DAP in 2003 $(P<0.10$; Fig. $1 C)$ and between 21 and 25 DAP in $2004(P<0.10$; Fig. $1 F)$.

Other researchers exploring conservation tillage for cabbage attributed yield reduction to temperature differences up to $4{ }^{\circ} \mathrm{C}$ between mulched and bare-ground treatments (Hoyt, 1999). By contrast, temperature differences of up to $3{ }^{\circ} \mathrm{C}$ did not reduce cabbage growth (Knavel and Herron, 1981). Wilhoit et al. (1990) recorded a $1.5^{\circ} \mathrm{C}$ difference between mulched and bare-ground treatments but concluded these differences were not enough to account for yield reductions observed because soil temperatures for all treatments ranged between 23 and $25{ }^{\circ} \mathrm{C}$, within the range conducive for plant growth.

In this study, increased tillage width from $15 \mathrm{~cm}$ (20\% surface disturbance) to $30 \mathrm{~cm}$ (40\% surface disturbance) had minimal effect on plant growth and yield (Tables 2 and 3) and no effect on internal color, external color and quality, or maturity date (data not shown). These results indicate that wider widths of soil disturbance did not increase soil temperature enough to improve 

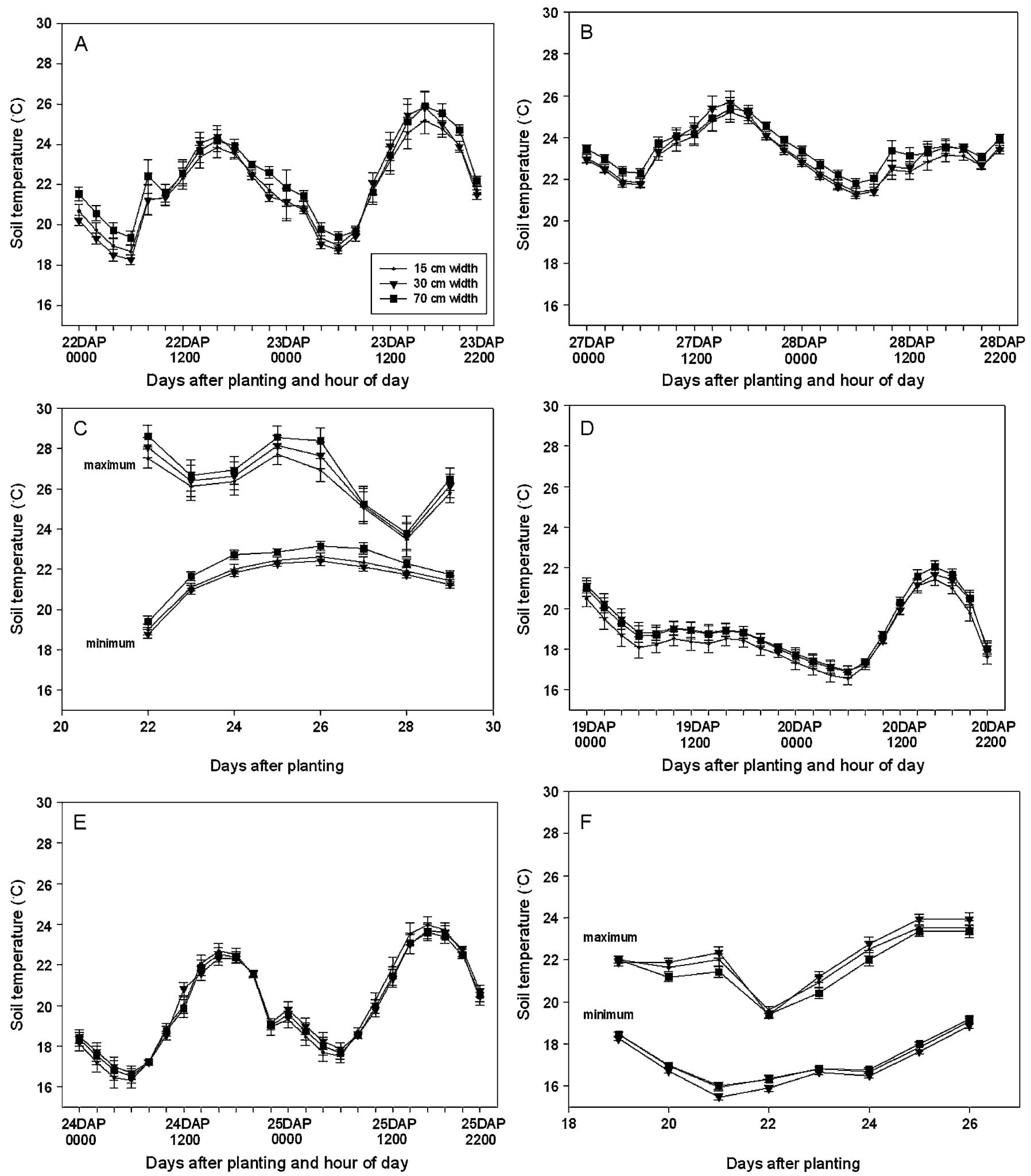

Fig. 1. Effect of tilled width on soil temperature. Data from 2003 include 2-hour average soil temperature (A) 22 to $23 \mathrm{~d}$ after planting (DAP) and (B) 27 to 28 DAP and (C) daily soil temperature maximum and minimum 22 to 29 DAP. Data from 2004 include 2-hour soil average temperature (D) 19 to 20 DAP and (E) 24 to 25 DAP and (F) daily soil temperature maximum and minimum 19 to 26 DAP.

crop performance in this reduced tillage system.

Later-season planting (June) allowed soils to warm and probably minimized the soil temperature reduction from reduced tillage treatments and potential delayed crop matu- rity. Delaying planting until soils warm can be an important management practice for success with this system in cool climates. For example, early-season planted tomatoes in the mid-Atlantic were delayed, but yields for the June-planted crop were not reduced
(Abdul-Baki and Teasdale, 1993). Similarly, no-till dry beans planted in New York in early June were not delayed because soil warming was less influential for crop establishment compared with earlier in the year (Kline, 1984). 
Table 2. Effect of tillage width, depth, and volume on aboveground biomass accumulation (grams per plant) in 2003 and 2004. ${ }^{\mathrm{z}}$

\begin{tabular}{|c|c|c|c|c|c|c|c|c|c|}
\hline & \multicolumn{4}{|c|}{2003 DAP $^{y}$} & \multicolumn{5}{|c|}{2004 DAP } \\
\hline & $\overline{14}$ & 28 & 58 & 71 & $\overline{14}$ & 29 & 44 & 56 & 71 \\
\hline \multicolumn{10}{|l|}{ Tillage } \\
\hline \multicolumn{10}{|c|}{ Width $(\mathrm{cm})$} \\
\hline 15 & 8 & 77 & 983 & 2461 & 7 & 67 & 450 & 1069 & 1350 \\
\hline \multirow[t]{2}{*}{30} & 7 & 88 & 1119 & 2725 & 7 & 67 & 424 & 939 & 1475 \\
\hline & NS & NS & NS & NS & NS & NS & NS & NS & NS \\
\hline \multicolumn{10}{|c|}{ Depth $(\mathrm{cm})$} \\
\hline 10 & 7 & 72 & 970 & 2419 & 6 & $60 \mathrm{~b}^{\mathrm{x}}$ & $375 \mathrm{~b}$ & 852 & 1239 \\
\hline \multirow[t]{2}{*}{30} & 8 & 92 & 1131 & 2767 & 8 & $74 \mathrm{a}$ & $499 \mathrm{a}$ & 1155 & 1585 \\
\hline & NS & NS & NS & NS & NS & $*$ & $*$ & NS & NS \\
\hline \multicolumn{10}{|c|}{ Volume $\left(\mathrm{cm}^{3}\right)$} \\
\hline 150 & 7 & 61 & 871 & 2193 & 7 & $68 \mathrm{ab}$ & $412 \mathrm{~b}$ & 907 & $1250 \mathrm{~b}$ \\
\hline 300 & 7 & 84 & 1069 & 2646 & 6 & $51 \mathrm{~b}$ & $338 \mathrm{~b}$ & 798 & $1228 \mathrm{~b}$ \\
\hline 450 & 9 & 92 & 1094 & 2729 & 8 & $68 \mathrm{ab}$ & $488 \mathrm{ab}$ & 1231 & $1450 \mathrm{ab}$ \\
\hline 900 & 7 & 92 & 1168 & 2805 & 8 & $82 \mathrm{ab}$ & $510 \mathrm{ab}$ & 1080 & $1721 \mathrm{a}$ \\
\hline \multirow[t]{2}{*}{1400} & 6 & 77 & 1022 & 2481 & 8 & $104 \mathrm{a}$ & $658 \mathrm{a}$ & 1188 & $1708 \mathrm{ab}$ \\
\hline & NS & NS & NS & NS & NS & $*$ & $*$ & NS & $*$ \\
\hline
\end{tabular}

${ }^{2}$ Planting dates were 9 June and 7 June, respectively.

yDays after planting.

${ }^{\mathrm{x}}$ Same letter denotes nonsignificant (NS) comparison in columns by treatment.

*Significant at $P<0.10$

Table 3. Effect of tillage width, depth, and volume on cabbage yield and head weight.

\begin{tabular}{|c|c|c|c|c|}
\hline & \multicolumn{2}{|c|}{ Yield (T per ha) } & \multicolumn{2}{|c|}{ Head wt (kg) } \\
\hline & 2003 & 2004 & 2003 & 2004 \\
\hline \multicolumn{5}{|l|}{ Tillage } \\
\hline \multicolumn{5}{|c|}{ Width $(\mathrm{cm})$} \\
\hline 15 & 48 & 51.6 & 1.7 & 1.7 \\
\hline \multirow[t]{2}{*}{30} & 52.7 & 47.5 & 1.8 & 1.5 \\
\hline & NS & NS & NS & NS \\
\hline \multicolumn{5}{|c|}{ Depth $(\mathrm{cm})$} \\
\hline 10 & $45.2 \mathrm{~b}^{\mathrm{z}}$ & 47.7 & $1.6 \mathrm{~b}$ & 1.6 \\
\hline \multirow[t]{2}{*}{30} & $55.5 \mathrm{a}$ & 51.4 & $1.9 \mathrm{a}$ & 1.6 \\
\hline & $* * *$ & NS & $* * *$ & NS \\
\hline \multicolumn{5}{|c|}{ Volume $\left(\mathrm{cm}^{3}\right)$} \\
\hline 150 & $42.9 \mathrm{c}$ & 52.7 & $1.5 \mathrm{c}$ & 1.7 \\
\hline 300 & $47.5 \mathrm{bc}$ & 42.6 & $1.6 \mathrm{bc}$ & 1.5 \\
\hline 450 & $53.1 \mathrm{ab}$ & 50.4 & $1.8 \mathrm{ab}$ & 1.6 \\
\hline 900 & $57.9 \mathrm{a}$ & 52.3 & $1.9 \mathrm{a}$ & 1.5 \\
\hline \multirow{2}{*}{1400} & $53.9 \mathrm{ab}$ & 44.0 & $1.7 \mathrm{ab}$ & 1.7 \\
\hline & $* * *$ & NS & $*$ & NS \\
\hline
\end{tabular}

${ }^{\mathrm{z}}$ Same letter denotes nonsignificant (Ns) comparison in columns by treatment.

${ }^{*, * * *}$ Significant at $P<0.10$ and 0.001 respectively.

Reducing tillage may inhibit crop growth by failing to break previously compacted soil, which can physically restrict root growth or reduce soil-to-root contact. Early in the 2003 season, treatments tilled to $30-\mathrm{cm}$ depth were less resistant than 10 - and 20 -cm depth treatments $(P<0.01)$ at 10 and $28 \mathrm{~cm}$ below the soil surface (Fig. 2A); these differences continued for the duration of the 2003 season, measurable $106 \mathrm{~d}$ after planting between 14 and $24.5 \mathrm{~cm}$ below the soil surface (Fig. 2B). Early in the 2004 season, treatments tilled to $30-\mathrm{cm}$ depth were less resistant than $10-\mathrm{cm}$ depth treatments between 5 and $30 \mathrm{~cm}$ below the soil surface $(P<0.10$; Fig. $2 \mathrm{C})$. The treatments tilled to $30-\mathrm{cm}$ depth were also less resistant than $20-\mathrm{cm}$ depth treatments between 17.5 and $25 \mathrm{~cm}$ below the soil surface at $17 \mathrm{~d}$ after planting in $2004(P<$ 0.10 ; Fig. 2C). By $104 \mathrm{~d}$ after planting in 2004, there were no differences in soil resistance among treatments (Fig. 2D). The effect of $30-\mathrm{cm}$ depth tillage to minimize soil
Tillage depth was a significant factor affecting plant growth in $2004(P<0.10$; Table 2). Treatments tilled to $30-\mathrm{cm}$ depth increased plant biomass accumulation 23\% and $33 \%$ at 29 and $44 \mathrm{~d}$ after planting, respectively, compared with $10-\mathrm{cm}$ depth treatments $(P<0.10$; Table 2$)$. At these dates, plants grown in the largest volume of tilled soil $(70-\mathrm{cm}$ width and $20-\mathrm{cm}$ depth, rototilled) were up to $90 \%$ larger than those grown in $150 \mathrm{~cm}^{3}(10-\mathrm{cm}$ width and $15-\mathrm{cm}$ depth) and $300 \mathrm{~cm}^{3}(30-\mathrm{cm}$ width and $10-\mathrm{cm}$ depth) $(P<0.10$; Table 2). By $71 \mathrm{~d}$ after planting, however, plants with a tilled volume of $900 \mathrm{~cm}^{3}(30-\mathrm{cm}$ width and $30-\mathrm{cm}$ depth) had outgrown those in 150 and 300 $\mathrm{cm}^{3}$ treatments by $40 \%(P<0.10$; Table 2$)$ and were similar to those in $450 \mathrm{~cm}^{3}(15-\mathrm{cm}$ width and $30-\mathrm{cm}$ depth) and similar to those in rototilled plots (Table 2). Despite these growth differences, tillage depth did not affect yield, head weight (Table 3), or head quality (data not shown) in 2004, in which higher than average rainfall may have reduced plant stress associated with soil compaction.

Cabbage growth and yield were similar among conventional tillage and reduced tillage systems that disturbed at least $450 \mathrm{~cm}^{3}$ per plant, indicating the undisturbed area between the rows in the zone tillage treatments did impede cabbage roots, which proliferate in a shallow mat (Weaver and Bruner, 1927; Wolfe, et al., 1995). The reduced tillage treatments left between $60 \%$ and $80 \%$ of the soil surface area undisturbed compared with conventional tillage and therefore prevented further tillage-induced compaction.

Increasing depth of tillage was more important to the success of this system than increasing width of tillage. Several reduced tillage studies for cabbage (Knavel and Herron, 1981; Wilhoit et al., 1990; Bottenberg et al., 1997) found soil temperature differences greater than those observed in this study, but only soil temperatures greater than $\approx 4{ }^{\circ} \mathrm{C}$ generated a cabbage response (Hoyt, 1999). Instead, soil compaction was the main factor associated with reduced yields (Knavel and Herron, 1981; Bottenberg et al., 1997), as was the case in this study. Conservation tillage for transplanted cabbage therefore requires active management of soil compaction, whereas soil temperature is of secondary importance.

Soil compaction management in reduced tillage systems balances the need to make previously compacted layers more friable without causing further compaction with tillage passes. Tillage to $30-\mathrm{cm}$ depth reduced compaction in this soil type and minimized surface disturbance compared with conventional tillage, but had similar cabbage growth and yield. Implementing a reduced tillage system that includes vertical tillage to $30-\mathrm{cm}$ depth can be an effective transition to conservation tillage without increasing soil penetration resistance or reducing cabbage growth and yields. 

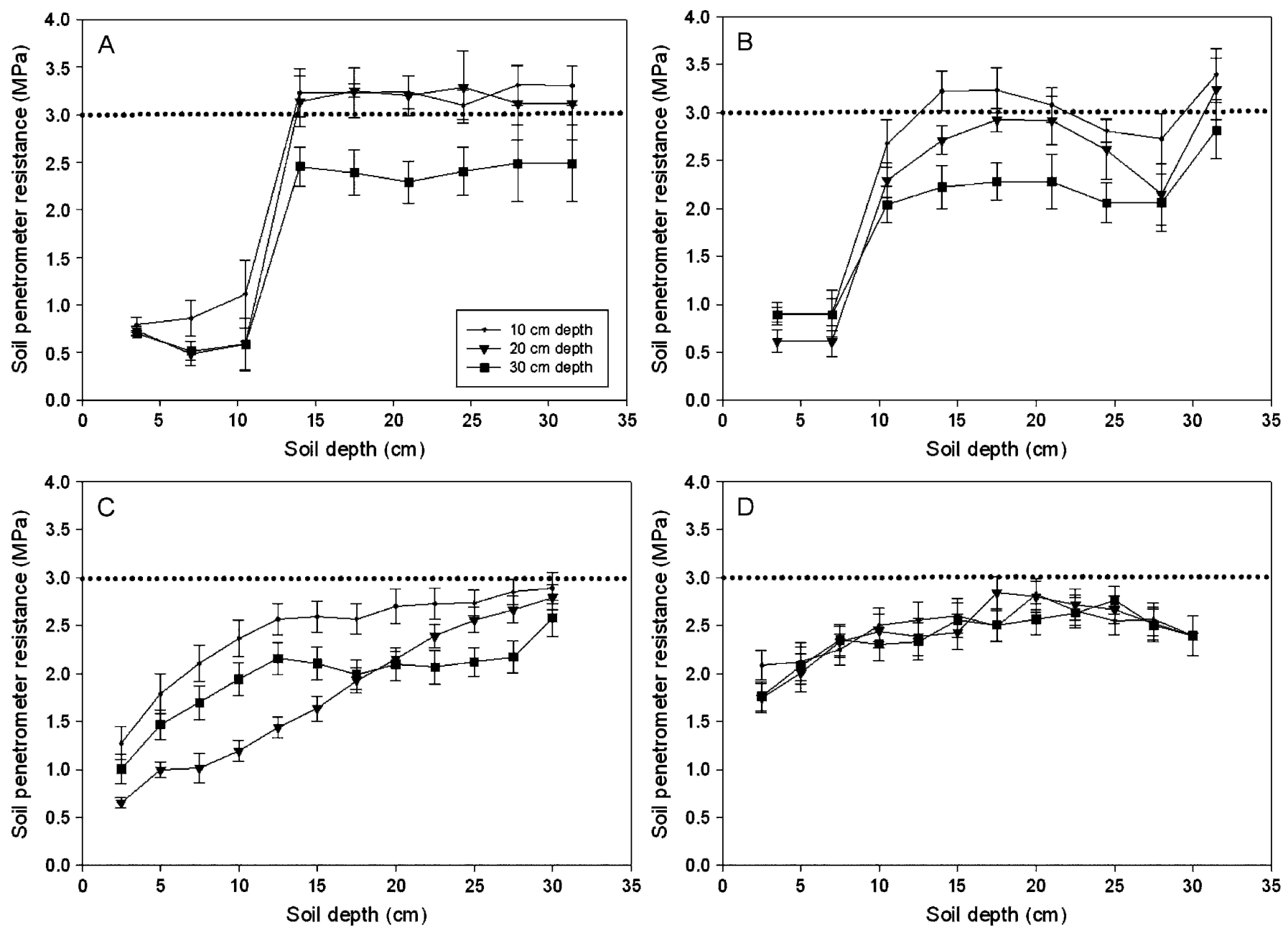

Fig. 2. Effect of tilled depth on penetration resistance. Data are penetrometer resistance values as a function of soil depth. Data from 2003 include (A) $16 \mathrm{~d}$ after planting (DAP) and (B) 106 DAP. Data from 2004 include (C) 17 DAP and (D) 104 DAP. The 3.0-MPa threshold above which plant growth may be limited is highlighted by a dotted line.

\section{Literature Cited}

Abdul-Baki, A.A. and J.R. Teasdale. 1993. A notillage tomato production system using hairy vetch and subterranean clover mulches. HortScience 28:106-108.

Bentley, O.G. 1977. Introduction to Dixon Springs Agr. Ctr. Ann. Rep. 5. Univ. of Illinois at Urbana-Champaign Agr. Exp. Stn. pp. II.

Bottenberg, H., J. Masiunas, C. Eastman, and D. Eastburn. 1997. Yield and quality constraints of cabbage planted in rye mulch. Biol. Agr. Hort. 14:323-342.

Cox, W.J., D.J. Otis, H.M. van Es, F.B. Gaffney, D.P. Snyder, K.R. Reynolds, and M. van der Grinten. 1992. Feasibility of no-till and ridge tillage systems in the northeastern USA. J. Prod. Agr. 5:111-117.

Cruse, R.M., K.N. Potter, and R.R. Allmaras. 1982. Modeling tillage effects on soil temperature, p. 133-150. In: P.W. Unger and D.M. Van Doren (eds.). Predicting tillage effects on soil physical properties and processes. ASA Spec. Publ. 44. Amer. Soc. Agr. and Soil Sci. Soc. Amer., Madison, WI.

Hoyt, G.D. 1999. Tillage and cover residue effects on vegetable yields. HortTechnology 9:351358 .
Johnson, A.M. and G.D. Hoyt. 1999. Changes to the soil environment under conservation tillage. HortTechnology 9:380-392.

Kline, W.L. 1984. Influence of reduced tillage systems on dry beans (Phaseolus vulgaris L.) grown in different crop residues. Cornell Univ., Ithaca, NY, PhD Diss.

Knavel, D.E. and J.W. Herron. 1981. Influence of tillage system, plant spacing, and nitrogen on head weight, yield, and nutrient concentration of spring cabbage. J. Amer. Soc. Hort. Sci. 106:540-545.

Laboski, C.A.M., R.H. Dowdy, R.R. Allmaras, and J.A. Lamb. 1998. Soil strength and water content influences on corn root distribution in a sandy soil. Plant Soil 203:239-247.

Loy, S.J.W., L.C. Peirce, G.O. Estes, and O.S. Wells. 1987. Productivity in a strip tillage vegetable production system. HortScience 22:415-417.

Magdoff, F.R. and H.M. van Es. 2000. Building soils for better crops. Handbook Series Book 4. Sustainable Agriculture Network, Beltsville, MD.

McKeown, A.W., R.F. Cerkauskas, and J.W Potter. 1988. Influence of strip tillage on yield, diseases, and nematodes of tomatoes. J. Amer. Soc. Hort. Sci. 113:328-331.

Northeast Regional Climate Center. 2004. The climate of Ithaca, NY. 15 Dec. 2004. <http://www. nrcc.cornell.edu/climate/ithaca/enhanced.html>.
Reiners, S. 2004. Cabbage, broccoli, cauliflower and Brussels sprouts. In: S. Reiners (ed.). 2004 Integrated crop and pest management guidelines for commercial vegetable production. 15 Mar. 2005. <http://www.nysaes.cornell.edu/ recommends/ 15 frameset.html $>$.

Soil Science Society of America. 2005. Glossary of soil science terms. Madison, WI. 15 Mar. 2005 $<\mathrm{http}$ ///www.soils.org/sssagloss/>.

Teasdale, J.R. and C.L. Mohler. 1993. Light transmittance, soil temperature, and soil moisture under residue of hairy vetch and rye. Agron. J. 85:673-680.

Weaver, J.E. and W.E. Bruner. 1927. Cabbage, p. 101-111. In: Root development of vegetable crops. McGraw-Hill, New York.

Wilhoit, J.H., R.D. Morse, and D.H. Vaughan. 1990. Strip-tillage production of summer cabbage using high residue levels. Appl. Agr. Res. 5:338-342.

Wolfe, D.W., D.T. Topoleski, N.A. Gundersheim, and B.A. Ingall. 1995. Growth and yield sensitivity of four vegetable crops to soil compaction. J. Amer. Soc. Hort. Sci. 120:956-963.

Young, H.M., Jr. and S.H. Phillips. 1973. Notillage: The ultimate? p. 11-20. In: No-tillage farming. No-till Farmer, Inc., Brookfield, WI. 